\title{
African Environmental Ethics and Sustainable Development
}

\author{
Mbih Jerome Tosam \\ Department of Philosophy, Faculty of Arts, The University of Bamenda, Bambili, Cameroon \\ Email: mtosam2002@yahoo.com
}

How to cite this paper: Tosam, M. J. (2019). African Environmental Ethics and Sustainable Development. Open Journal of Philosophy, 9, 172-192.

https://doi.org/10.4236/ojpp.2019.92012

Received: February 24, 2019

Accepted: May 5, 2019

Published: May 8, 2019

Copyright $\odot 2019$ by author(s) and Scientific Research Publishing Inc. This work is licensed under the Creative Commons Attribution International License (CC BY 4.0).

http://creativecommons.org/licenses/by/4.0/

\begin{abstract}
In this paper, I argue that African environmental ethics can contribute to sustainable development as well as mitigate the devastating effects of global warming and climate change in Africa. Although Africa bears the least onus of responsibility for global warming and climate change, she suffers the greatest burden of the adverse effects of global climate change and environmental crisis. While industrialized countries, nations which are largely responsible for the greatest amount of greenhouse emissions are laggard and reticent in implementing international agreements aimed at palliating the untoward effects of climate change, there is an urgent need to seek indigenous solutions to environmental crisis in Africa without compromising the much needed development in the continent. African environmental ethics extends the moral community beyond anthropocentric concerns by including non-human animals, plants, the unborn, and the supernatural into the moral universe. I use Kom environmental ethics to show how indigenous African societies employed different values and customs to make their environment physically and spiritually sustainable. There were taboos, values, and norms which prescribed correct behavior towards nature. But as a result of the colonial encounter, Africans were forced to abandon some of these indigenous environmental values and sustainable practices for an anthropocentric approach. With this outlook where humans have moral responsibility only towards humans, development meant the complete disregard for traditional African holistic values and customs. This disregard, in conjunction with weak or absence of institutional framework regarding environmental protection and corruption in the management of natural resources, has led to unsustainable exploitation of the natural environment in Africa.
\end{abstract}

\section{Keywords}

African Ethics, Environmental Ethics, Holism, Sustainable Development, Indigenous Values, Kom Environmental Values 


\section{Introduction}

Today we are faced with a challenge that calls for a shift in our thinking, so that humanity stops threatening its life support system. We are called [upon] to assist the Earth to heal her wounds and in the process heal our own ... This will happen if we see the need to revive our sense of belonging to a larger family of life ... (Maathai, 2010: p. 272).

Some scholars have argued that Africans have little or nothing to contribute to environmental ethics because African ethics is essentially anthropocentric (Callicot, 1994: p. 158). Such claims are easily corroborated by the irrational and unsustainable destruction of flora and fauna, unregulated mining activities, which have greatly degraded the quality of the environment, the consequent burden of the negative impact of climate change on the continent, as well as Africa's parallel incapacitated capitulation to the dictates of global warming and climate change. Contrary to this view, I argue that African environmental ethics, like African ethics is not at all anthropocentric, but rather holistic and all-encompassing. This deeply-rooted environmental holism can be perceived in African metaphysico-religious and moral outlook regarding nature (Tangwa, 1996; Kelbessa, 2006: p. 21; Behrens, 2010; 2014: p. 66; Ikuenobe, 2014). However, apart from critiquing African environmental values, there has been very little attempt to examine in what way(s) these values can be employed to achieve sustainable development. It would be in the benefit of Africans to critically study indigenous environmental ethics, to see in what ways it could conduce to the efflorescence of the African, mitigate the unfavorable effects of climate change, rather than completely disregard it.

The argument is based on the understanding that each society's perception of nature profoundly influences the way it treats nature, and how a society relates with nature can either enhance or degrade the health of the environment. If we perceive nature as something which we (humans) are an integral part of, and as equal partners, with whom we share a common habitat, then we may treat it with respect (Gratani et al., 2016: p. 2). But, if we regard nature as something inferior to us, we may treat it without respect. The anthropocentric worldview which regards nature as inferior to humans who therefore have a mandate to dominate and exploit it, constitutes the underlying modern Western philosophical view of nature, and has contributed, arguably, to the unsustainable exploitation of the natural environment. Global warming, and the concomitant environmental and health challenges it has provoked, have been attributed to the modern techno-scientific spirit of omnivorous and unrestricted exploration and exploitation of nature.

Before the colonial encounter Africa had a different worldview and attitude amongst indigenous people towards nature. The traditional African attitude towards nature was that of live and let live, be and let be, which favored sustainable management of natural resources. It is from this perspective that Ikuenobe (2014: p. 2) avers that "the activities that have raised environmental concerns in 
Africa did not exist prior to colonialism because Africans had conservationist values, practices, and ways of life". European colonization in Africa introduced a materialist worldview which encouraged the subjection and destruction of the traditional African holistic and conservationist values and practices. Traditional Western ethics was anthropocentric, ascribing very little or no moral worth to non-human creatures (Gudorf \& Huchingson, 2010: p. 4). In spite of the rapacious nature of colonization on African cultures, some of these values have endured. African environmental consciousness can be seen in some traditional religious and metaphysical beliefs, customs and practices which stem from their daily experiences and reflections about nature (Kelbessa, 2006: p. 18).

In this paper, therefore, I argue that it is time for African governments to start appraising and encourage the re-institution of traditional conservationist values and practices to help extenuate the adverse effects of climate change in Africa and promote sustainable development on the continent. It may, however, be overly simplistic to think that the current environmental challenges in Africa have been primarily caused by colonialism. African countries have also contributed to climate change, for its intensity and untoward effects, and for most of the environmental problems the continent is currently confronted with. The United Nations Economic Commission for Africa has pointed out that Africa lacks "adequate strategy and focus on the management of its natural resource base" (UNECA, p. 2012). Most African countries lack the institutional framework and laws regarding environmental protection, and where such institutions exist, they are very weak or completely dysfunctional or, are for the most part, mired by corruption. Poor and opaque management of natural resources, the construction of big dams which cause untold environmental problems, amorphous mining activities, and unrestricted exploitation of forest and water resources, have led to various forms of human-induced natural catastrophes on the continent such as drought, landslides, erosion of fertile farmland.

Although ethics, especially in the Western philosophical tradition, was traditionally concerned with relations between human beings (rational beings), in the last half a century, or so, Western philosophical scholarship has increasingly come to the realization that humans are neither morally superior nor special creatures. Human beings are only one among several species that make up one big family called nature, and for that reason, moral responsibility is not only owed to humans, but ought to be extended to the rest of nature. Environmental philosophy was born out of the recognition that our neighbor is not only a fellow human, but, also, nature as a whole. Hence, an eco-philosophical rendition of the biblical saying: "Love your neighbor as you love yourself" (Matthew 22:34-40), will imply extending love and compassion beyond human beings to include nature in our moral consciousness.

According to African traditional environmental ethics, human beings are mere co-occupants of nature with other species without any heavenly mandate to dominate, subdue, and exploit nature. This attitude toward nature is diametrically opposed to the mechanistic and anthropocentric outlook initiated by Francis 
Bacon and Rene Descartes, which perceives humans as privileged members of the ecologic community with the moral authority to subdue, control, and monopolizes the rest of nature. I am not, however, claiming that African environmental ethics alone would promote sustainable development. My contention is that a critical reappraisal and return to traditional environmental practices, in tandem with adequate political commitment towards environmental conservation, may contribute to sustainable development in Africa. I critically investigate some indigenous sub-Saharan African environmental ethical values which may contribute to sustainable development.

As a result of the mastery of, and the unprecedented progress in science and technology, the Western world has acquired a certain epistemological arrogance where it considers itself as the prophet and master in every aspect of life including human development. As self-imposed masters over other peoples and cultures, the West considers itself as having a moral or even a sacred mandate to illuminate other parts of the world considered to be savage. The colonizing mission to Africa and other parts of the world was informed and guided by this redemptive ambition. Based on this 'know it all' attitude, Western systems of thought and perspective on development, and on everything else, was imposed on the rest of the world through colonization and is perpetuated today through globalization. It is for this reason that in mainstream environmental philosophy today, "non-western knowledge is not always the source of ecological wisdom" (Kelbessa, 2006: p. 27) as a result of the silence imposed on African ecological knowledge by the colonialists. Western culture has developed a high level of resistance and impenetrability against perspectives, values and standards from other cultures except in domains where there are ineluctable consequences of its rapacious actions (Tangwa, 1996: p. 185). This is an attitude that has resulted in an epistemological injustice against non-Western systems of knowledge.

\section{The Relation between Environmental Ethics and Sustainability}

Environmental ethics is a sub-field of ethics which is concerned with the ethical relation between humans and the natural environment. Environmental ethics seeks to extend ethics beyond its traditional inter-human moral relationship to include non-human features of nature in our moral consideration. Environmental values are a set of beliefs about what is good and evil, right and wrong, just and unjust, beautiful or ugly about, or in relation to the environment. Environmental ethics attempts to inquire into the moral status of nature. In doing so, it applies the concepts, principles, and theories in traditional moral and political philosophy to address environmental questions. Some of the fundamental questions environmental ethics seeks to address include the following: 1) Why is it important to care about nature for itself? 2) When the natural environment, landscape, flora and fauna, are destroyed what is the overall consequence to humankind? 3) Will future generations be deprived of some species because of our actions today? 4) Do humans have a need for nature that implies a moral obliga- 
tion to preserve it? (Michael, 2005)

Although philosophers throughout history have raised questions concerning the moral relationship between humans and the moral worth of the environment, it was only in the 1960s and 1970s that environmental ethics emerged as a distinct field of philosophical investigation. It was then that calls for the expansion of the moral community to include the environment began. In a ground breaking article, Aldo Leopold called on humans to expand their moral vista of the community "to include soils, water, plants, or collectively: the land" (1966: p. 239). Today, Western environmental philosophy has become the most overriding in the discourse on environmental ethics. Non-Western perspectives and orientations have remained largely unexplored or simply silenced. On the other contrary, environmental consciousness has always been an essential part of African traditional ethics. This can be viewed in the holistic African moral outlook which incorporates the anthropological, ecological and spiritual components of reality. In the past two decades, there has been increasing scholarship on African environmental ethics which could be considered as Africa's contribution to mainstream environmental ethics (Tangwa, 1996; 2004; Kelbessa, 2006; Behrens, 2010; 2014; Ojomo, 2011, Ikuenobe, 2014). However, most of these scholars have hardly explored the nexus between indigenous environmental ethics and sustainable development.

Closely linked to environmental ethics is the idea of sustainability. The United Nations document on sustainability, Our Common Future, defines sustainable development as "development that meets the needs of the present without compromising the ability of future generations to meet their own needs" (WCED, 1987). At the core of the concept of sustainability is the idea of the moral responsibility of the present generation, solidarity, and justice, towards future generations. The idea of sustainable development is born out of the desire to achieve economic growth for all, rich and poor, without harming the health or quality of the natural environment. This idea emerged from the informed observation and conviction that the recent environmental changes experienced during the $20^{\text {th }}$ century was the result of "the cumulative and unintended result of human economic activity" (Holland, 2001: p. 390). Such economic activity has led to the "exhaustion of natural resources, extensive pollution, and impact upon climate, life-forms, and life-sustaining systems" (Holland, 2001: p. 390), all of which are prejudicial for future generations.

There is, therefore, an inextricable relation between environmental ethics and sustainability. Both concepts are concerned with the preservation of ecological integrity and diversity, the meeting of basic human needs, the conservation of the environment for future generations, the protection of indigenous rights over the use of their lands including respect for their cultural values and beliefs about the environment. As Van Horn (2018) sagely put it:

Sustainability lacks a generative purpose and ceases serving as a guide for reflection if we do not consider the ... values, cultural worldviews, and me- 
thods for achieving durable, just, and mutually enhancing human-nature relationships. Sustainability offers traction to the idea that we are obligated to consider future generations in our policies, in our production and consumption of material goods, in our very interaction with the natural world, and in our daily decision-making.

Sustainability, like environmental ethics, defends the idea of the preservation of the environment for future generations, respect for indigenous environmental values, and the recognition that human beings are not the only creatures in nature that morally matter. To give credence to the idea of the intimate link between environmental ethics and sustainability as it obtained in African traditional society, Kwasi Wiredu, though not an advocate of holistic environmentalism, proffers:

Of all the duties owed to the ancestors, none is more imperious than that of husbanding the resources of the land so as to leave it in good shape for posterity. In this moral scheme, the rights of the unborn play a cardinal role that any traditional African would be nonplussed by the debate in Western philosophy as to the existence of such rights (Wiredu, 1994: p. 46).

For Wiredu, it was a moral duty for the living to preserve a healthy environment for future generations. From this perspective, in traditional African culture, our moral responsibility was not only limited to the present generations, which is one of the fundamental canons of sustainability.

\section{African Environmental Ethics: A Kom Perspective}

It has been argued that African ethics is fundamentally anthropocentric (Wiredu, 1980; 1983), and African environmental ethics, by extension, is anthropocentric with very little or nothing to offer in the field of environmental ethics (Callicot, 1994: p. 158). Others, on the other hand, argue that humanism or anthropocentrism cannot be the basis of African ethics because it "fails to capture some of the prevailing thoughts and intuition we Africans typically have about our duties towards the natural environment" (Molefe, 2015: p. 59). Hence, African ethics, and environmental ethics, is essentially holistic including anthropocentric, ecocentric, and supernatural tendencies in its moral worldview (Buju, 1997; Molefe, 2015; Tosam, 2016).

Kom environmental ethics can be easily seen in traditional and contemporary Kom ecological beliefs, customs, and practices. Some of these values are also expressed in Kom orature. Kom environmentalism is holistic and includes humans, the ecosystem, spirits, the living dead, as well as the unborn in the moral community. In this integrated view of the universe, there is an expanded conception of the community as a continuum of the natural and the supernatural, of the present and the future member. It is from this perspective that it can be argued that African environmental ethics goes beyond the anthropocentric to the ecological and supernatural spheres. For example, in Kom culture, it is forbidden 
to cut any plant at night with a machete. However, if one must do so, he/she must make incantation "yi leu'si itu $\dot{t} y v \dot{t}$ ", translated as "take way your heads." This statement is aimed at spirits who are believed to incarnate plants at night and if wounded may be reborn with cleft lips. Tangwa posits that it may be incorrect to characterize African environmental philosophy as "either eco-centred, bio-centred or anthropo-centred" (1996: pp. 188-189); because it is an all-encompassing moral intuition. It is for this reason that Tangwa describes this interconnected and interdependent African outlook as "eco-bio-communitarian" (2004: 387-395). This involves the "recognition and acceptance of inter-dependence and peaceful coexistence between earth, plants, animals and humans" (Tangwa, 2004: pp. 387-395) in a hierarchy of being. On his part, Ikuenobe (2014: p. 2) appositely captures this African holistic worldview as follows:

Reality is seen as a composite, unity and harmony of natural forces. Reality is a holistic community of mutually reinforcing natural life forces consisting of human communities (families, villages, nations, and humanity), spirits, gods, deities, stones, sand, mountains, rivers, plants, and animals. Everything in reality has a vital force or energy such that the harmonious interactions among them strengthen reality.

There is a necessary and mutually beneficial link between all facets of reality which is considered to begin and end with God as creator and sustainer of the universe. Behrens (2014) has described this African environmental philosophical outlook as "relational environmentalism". Humans, nature, and the supernatural world depend on each other, and it is not for the sake of their safety and survival that humans protect nature, as it is the case with anthropocentric environmentalism, but for their common well-being and survival.

In Kom thought, there is no clear separation of reality between subject and object, spiritual and material as it is commonly the case in Western thought. As Buju (1998: p. 209) rightly opines with regard to traditional African though, "all beings, organic and inorganic, living and inanimate, personal and impersonal, visible and invisible, act together to manifest the universal solidarity of creation". In this sense, therefore, according to Kom ontology, human beings are equal co-occupants of the universe with the rest of nature, and as co-occupants, they do not compete, but rather cooperate with other members of the ecological community. The people are not, and do not, try to transform themselves into masters and possessors of nature as the Cartesian worldview depicts. There is therefore an insoluble and necessary connection between all the forces of nature within the universe without which there will be no harmony. Hence, according to this Kom conception, the health of the environment is inherently linked to the health of humans, animals, plants, the spiritual realm, and the whole ecosystem that provides protective covering for these beings. In this regard, any unsustainable exploitation of nature was considered evil or sacrilegious.

The Kom people have a profoundly religious view of the cosmos. Nature is revered because it is believed that the spirits or the gods dwell in the natural en- 
vironment, the forest, rivers, valleys and mountains around. It was believed that humans with extraordinary powers can transform into other animals or creatures. The kom people believe that spirits cohabit their natural environment. Therefore, the sacred days of the week-ituh iboli and iyvi ni Kom, nobody goes farming because other spirits do farm on these days. For example, in the Nso community (in the North West Region of Cameroon), "the weak, the poor, the deformed, and the physically handicapped are particularly respected because of the belief that such persons usually possess extraordinary 'depth', have unusually powerful spirit-gods, or are frequently used as disguises by the spirits or by God" (Tangwa, 1996: p. 190).

In traditional Kom society the belief in totem was very common. Different sub-clans or communities had different animal species as their totem. Although this practice is fading because of the influence of Christianity on Kom thought, it is still held that some people with supernatural powers have the capacity to transform into some animal or pant species. The people were expected to respect and show compassion for the totem, and the totem in turn is supposed to help them in times of despair. In communities where animals are honoured as totems, there were taboos, laws, proscriptions against the killing of such animals except in self-defence. There were taboos against the killing of pregnant animals, young animals, sick animals, and the exhaustion of a species. Special rites and prayers were offered before some trees were felled down. For example, before a cola nut tree is cut down in Kom society, prayers, sacrifices, and rituals are performed. The belief in and practice of totemism is informed and influenced by the Kom metaphysical idea that there is no distinction between the human and the natural world. This African integrated and interdependent conception of nature is summarized as follows: "we are the environment and the environment is us: we are united and identify with nature" (Gratani et al., 2016: p. 13).

In the same light, Tempels avers that in African ontology, "a human group and an animal species can occupy in their respective classes a rank relatively equal or relatively different. Their vital rank can be parallel or different. A chief in the class of humans shows his royal rank by wearing the skin of a royal animal" (Tempels, 1969: p. 61). In Kom royalty is expressed by putting of feet on a leopard skin and the Fon (king) is referred to as the Leopard. In other parts of sub-Saharan Africa, some societies showed profound respect for certain animal species by either clapping or prostrating when they saw an animal species that represent their group totem. Also, it is believed that persons of certain stature could transform into such animal or plant species. Some animals simply symbolized power and royalty. For example, in traditional Nso' society, the people clapped or bowed down when they saw a lion, because it symbolizes royalty and power. In the Nso' land, "the King (Fon) is ... believed to be capable of transformations as an aspect of his kingly attributes" (Tangwa, 1996:191). This goes to reinforce the view that there exists no clear distinction between the natural and the supernatural in the African conception of reality. Tangwa further asserts: 
With the African outlook, human beings are more humble and more cautious, more mistrustful and unsure of human knowledge and capabilities, more reconciliatory and respectful of other people, plants, animals, inanimate things, as well as sundry invisible/intangible forces, more timorous of wantonly tampering with nature, in short, more disposed towards an attitude of live let live ... Within the worldview, the distinction between plants, animals and inanimate things, between the sacred and the profane, between matter and spirit, the communal and the individual, is a slim and plastically flexible one (1996: p. 191).

This relational outlook where there is no clear separation between humans and the rest of nature and, even between the living and the dead, has engendered a tolerant and reverential attitude towards all living and non-living things. In this bounded universe, to remain healthy, one must live in harmony, not in opposition, with the rest of nature.

In Kom society people have rights and duties not only towards one another, but also towards nature. For example, there are proverbs which show the Kom people's attitude towards sustainable management of the environment. The following proverb highlights this idea: Wà kce àjvà wa fayti tinten, which translates as: when you harvest garden eggs, mend its branches. The idea invoked in this maxim is that if you benefit from something then use it sustainably because you, as well as other members of the community, will always need it for your survival. It was therefore morally wrong to completely expend a species. In traditional Kom society, people owned property in common. You could go to anybody's farm and harvest any crop provided you harvested only the quantity necessary to assuage your hunger. If you harvested too much it would be considered as stealing because your action would be inconsiderate. In some African communities there are moral codes and practices which regulate inter-human and inter-species relationship. For example, in the Oromo society in Ethiopia, Saffu is used to guide the proper, fair, and sustainable management of the environment (Kelbessa, 2006: p. 24).

There are beliefs and customs associated with farming and agriculture which encourage environmental conservation. For example, in the Kom land, the farming season is usually preceded by rituals and sacrifices called fichuoh. The fichuoh usually takes a whole week of abstention, rituals prayers and sacrifices to the gods of fertility. During this week seeds are blessed by the village chief priest.

In traditional Kom society, the forest was sacred and well-protected against any form of human or natural peril. Hence, farming and hunting was prohibited in such specially preserved forests. The universe was viewed as God's creation and $\mathrm{He}$ was considered to be found in all of His creatures. Hence, humans, plants and animals, the earth, and the rest of nature were all infused with spirits and forces. In this regard, there were forests and trees which were specially preserved for spiritual as well as material good including initiation rites, religious ceremonies, medicine, food, human well-being, and biodiversity protection. For 
example, there were forests specially preserved for medicinal purposes commonly called akua mift (forest for medicines). Some of these akua mif have been destroyed to as a result of the ever-increasing Kom population, disregard for traditional ecological values, and the effect of climate change on the environment.

It is evident from the above analysis that African environmental ethics is not essentially anthropocentric, but holistic. In what follows, I shall show that environmental holism engenders a moral outlook which is also inclusive.

\section{Nature and Moral Consciousness in the African Universe}

Why do Africans protect nature? Is it for its own sake or for the sake of human flourishing? If it is for its own sake, then African environmental ethics is pure environmentalism. If it is for human efflorescence, then African environmental philosophy is anthropocentric, at least a soft form of it. These are some of the fundamental questions of environmental ethics, which can be interrogated about any environmental ethical tradition. The conservation of nature in African ecological outlook is both for human and for the environmental survival. The interests of the two are coextensive. It is for each other's interest that the environment must be protected. In this context, there is no separation between human interest and nature's interest, since "both interests are mutually reinforcing. The respect for nature thus serves human interests, given that humans are an integral part of nature. The use of nature for serving human needs which may appear to be aiming at human self-interests is actually a way of respecting and bringing about harmony in nature ..." (Ikuenobe, 2014: p. 9)

Contrary to the predominant Western ethical view where moral worth is imputed only to rational or sentient agents, in the African moral worldview, even beings which do not possess rational capacities like foetuses, neonates, plants and animals are accorded moral worth. Here, "moral responsibilities are anthropocentric, but not morality itself" (Tangwa, 1996: p. 189). Although humans have moral responsibility, human beings do not consider themselves as privileged beings with a heavenly mandate to conquer, control and exploit the rest of nature. Human well-being as the aim, end and purpose of morality. Because human beings live in a harmoniously integrated cosmos, where they depend on other beings, to survive, they must grant equal worth to the other members of the universe. In this moral universe, only humans have moral obligations towards the environment. For example, there were "strict taboos on eating or killing certain insects, reptiles, birds and animals" (Tangwa, 1996: p. 189), which guaranteed the survival of fauna and flora. There were also proscriptions against killing pregnant animals and in case such animals were killed by error, this required ritual cleansing and purification. There were taboos against the killing of domestic animals reared mainly for purposes of companionship and assisting humans such as dogs, cats, horses and donkeys.

In the Western world, some environmental ethicists are beginning to see need 
to include non-human aspects of nature in the moral community. Arnes Naess (1989: p. 32) has emphasized the need for the expansion of our moral perspective to include the rest of nature:

The further maturation of the human species will involve "identification with all life forms" and "the acknowledgment of the intrinsic values of these forms" in an expanding circle of moral obligations. Moving outward from oneself, the circle will include duties to our family and relatives, our local community, our country, all humanity, mammals (save the whales!), all animals, save the snails darter), all species (save the Yellow lady Slipper Orchard) ecosystems (save the rain forest), and ultimately the whole earth. Such an expansion of ethical concerns involves new limitations on acceptable actions, but also new opportunities for personal growth and flourishing.

The moral universe that Naess is advocating for her, and which considers humans as part of nature, without any special rights or privileges, has always been an essential part of African metaphysical and religious worldviews before the colonial encounter.

Moreover, because nature is the dwelling place of the gods, spirits, and ancestors, abusing nature is tantamount to abusing the spiritual realm, and therefore an invitation for disharmony and disaster. Such catastrophe may not only affect the violator, but also his/her entire family and community including the present, the living-dead, and the unborn. Humans therefore have a moral duty to protect nature because it is just to do so. While we use nature for our own benefit, it behooves us to exploit it sustainably in order not to trigger disharmony and imbalance between the various forces in nature which may be calamitous for both parties. It is this harmony that helps maintain the physical and spiritual health of the universe. The environment is "useful to humans, but such usefulness is also dependent on the need for harmony in nature for its own sake. This is the reason why nature is viewed holistically and it is morally respected and given due reverence for its own sake" (Ikuenobe, 2014: p. 9). In most African cultures, it is commonly thought that ill-health, natural catastrophe, or any misfortune is triggered by imbalance in some part of nature or so. To forestall ill-health or any natural catastrophe, we need to always seek to maintain harmony in nature. It is therefore for our own good and the good of nature that we must not provoke the wrath "of the gods, spirits and ancestors by mistreating nature ... their dueling places" (Ikuenobe, 2014: p. 10). Hence, by respecting nature, we are morally respecting the gods, spirits, ancestors, and God.

\section{Environmental Crisis in Africa}

Natural and human-induced factors have contributed to the environmental crisis in Africa. The unbridled dependence on wood as a source of fuel, over-cultivation and over-grazing, in most African communities, has put untold pressure on natural resources, which is affecting the ecosystem and biodiversity. As African countries seek to industrialize and modernize their economies, this has resulted 
in population explosion, which has put untold pressure on the environment. These have resulted in the intensification of global warming and climate change, exposing the environment to drought, fires, storms, floods, all of which disrupt the supply of safe-drinking water, food, health services and economic activities (Tosam \& Mbih, 2015: p. 789). Environmental pollution resulting to water and airborne diseases are a cause for the intensification of poverty as it largely affects the working and most productive part of the population. In the same connection, climate change-induced natural disasters like flooding and landslides have destroyed fertile farmland, shelter, increased the possibility of standing water and high incidence of malaria and dengue fever.

Moreover, the poor use of natural resources has led to excessive environmental degradation, again leading to the emergence and re-emergence of new and old pathogens, which are considered by the World Health Organization (WHO) as the diseases that are "likely to cause severe outbreaks in the near future, and for which few or no medical countermeasures exist" (WHO, 2015). There has been the emergence of new pathogens like the tick borne disease, MERS and SARS, Marburg, Zika, Lassa fever, and old ones like mycobacterium tuberculosis, Ebola virus disease, literia moncytogenes, enterococi and different forms of fungi. Some of these diseases have developed resistance to antibiotics, while others have been recurrent in some African countries like Liberia, Benin, Guinea Conakry, Sierra Leon, D.R. Congo, Uganda, among others in the last fifty years.

The construction of large dams and unregulated mining activities have caused the destruction of natural habitat for some animal and plant species and forced the displacement of indigenous people in some areas. The high demand for power to energize Africa's growing industries coupled with the growing population has compelled some African countries to construct large dams to meet the energy needs of their countries. Large dams planned and constructed without consideration of downstream impacts disrupt the normal flow of rivers and watersheds, with serious consequences on the environment like coastal erosion, pollution, and destruction of ecosystem. A recent example is the collapse of an iron ore taillings dam in Brumadhino, Brazil on the $25^{\text {th }}$ of January 2019, releasing 11.7 million cubic metres of toxic mud. More than 171 people have been confirmed dead and 141 are missing, and destroying about $500 \mathrm{~km}$ of land and rendering many people homeless (Senra, 2019). The retention of water in dams delays and reduces floods downstream, which affects the ecosystems and the reproductive variations of the animals and life forms in the area.

In the same connection, the high demand for extractive minerals has led to an exponential increase in mining activities in Africa, although not without great potential for infrastructural and socioeconomic development, has severe consequences on the environment and biodiversity. The extraction of targeted minerals usually result in the production of large volumes of waste material that remain after the natural resources have been extracted such as mixtures of crushed rocks and other processing fluids. These waste products damage the natural en- 
vironment (Kossof et al., 2014: p. 230). They result in erosion, sinkholes, loss of biodiversity, contamination of soil, ground and surface water by chemicals released from mining activities with dire consequences on environmental and human health. The environmental situation in Africa has been further aggravated by the activities of multinational companies which are engaged in oil, gas, timber exploitation, and land grabbing. Moreover, there is population migration and destruction of protected lands in the areas where the extractive industries are located. For example, with the opening of the Geita Mines in Tanzania, the population of the town quadrupled in three years from 30,000 in 1999 to 120,000 in 2002 (Edwards et al., 2014: p. 304). All of these contribute to the degradation of environmental health and provoke climatic change. The consequences of all these has been "increased temperatures, desertification, increased scarcity of water, frequent droughts, changes in glacial mass balance, increased incidence of extreme weather ..." (Kelbessa, 2015: pp. 406-407), which affect soil quality needed for farming, and is also at the basis of farmer-grazier and other conflicts related to environmental degradation. If Africa has to achieve lasting development, it must not ignore its traditional conservationist methods of sustainable use of natural resources.

\section{Promoting African Environmental Values for Sustainable Development}

Is it possible to respect African traditional conservationist values and still achieve the development goals of the continent with the ever-expanding populations and growing economic needs of African nations today? This question is especially important today because the continent is the most affected by the adverse effects of global climate change and also the least developed economically. The increasing impact of climate change in Africa is a serious threat to development. Climate change is affecting agriculture and food security, water, energy, infrastructure, and health, with serious consequences on the economic and political stability of the continent. Climate change has provoked natural disasters such as famine, droughts, floods, landslides, ignited new and old health problems, and climate change-related conflicts. I have shown that it may not be possible to achieve sustainable development by sticking to the Western capitalist model because it is arguably one of the principal causes of the current global environmental crisis.

Modern Western anthropocentric outlook has its roots from the Judaeo-Christian tradition, which places humans at the centre of the universe with a mandate to explore, dominate, and exploit nature, especially if it has commercial value. This voracious modern scientific project, promoted by Bacon and Descartes, and instigated by the lure to conquer and control everything, led to the "secularization, desacralization and profanation of everything in the universe ..." (Tangwa, 1999: p. 220). The Industrial Revolution with its concomitant techno-scientific desire for edacious discovery, which, however, was not without positive value to hu- 
manity, gave the modern world a new impetus for its mechanistic and capitalist agenda, and led to immoderate exploitation of nature. The mechanistic outlook considers human development as primarily concerned with the material transformation of nature. However, it may easily be argued that the reason why Africa has not attained the same level of development, compared to other regions of world, is because of herinability to transform nature. Other societies have been able to develop because they were able to subdue and control the forces of nature, instead entertaining a harmonious and reverential relation with it. This inclusive and holistic approach to development cannot be achieved by ignoring other cultural perspectives as worthless even before we engage in their critical scrutiny.

Sustainable development cannot be achieved by considering other cultural ecological values as worthless. Buju (2009: p. 288) argues that Western technological outlook does not "contribute towards making the world more human"; instead of promoting life, it has promoted death. It is "only when the technological world listens to the symbolic language of nature will it become literate once more and able to promote life instead of death" (Buju, 2009: p. 288). To make the world more humane, therefore, is to respect nature, and this can only be possible if we respect other cultures, especially cultures that perceive humans and nature as equal and interdependent members of the community and not opposed to each other. Hence, the future of humanity lies in values that promote culture because "without them, there is no future, not even for technology" (E. Mveng cited by Buju, 2009: p. 288).

In traditional Africa, development was not considered as merely material, in terms of the material transformation of nature, but a process that was in harmony with all the forces of nature. African holistic environmental values can contribute to sustainable development. Restoring some of these values could also contribute to sustainability and environmental justice in Africa. African environmental values, practices and approaches are cost-effective and culturally acceptable since they constitute an important part of the culture of the local communities. Besides, because the people are directly involved in the management of natural resources, it is less likely to fail, and may therefore be more sustainable, as compared to modern methods of environmental conservation. The Convention on Biological Diversity (CBD) emphasizes the fundamental importance of indigenous values and knowledge in achieving sustainable development. For example, Article 8 (j) states that:

Subject to National Legislation, to respect, preserve and maintain knowledge, innovations and practices of indigenous and local communities embodying traditional lifestyles relevant for the conservation and sustainable use of biological diversity and promote their wider application with the approval and involvement of the holders of such knowledge, innovations and practices and encourage the equitable sharing of the benefits arising from the utilization of such knowledge, innovations and practices. 
According to the $\mathrm{CBD}$, indigenous values, knowledge systems and practices are essential for sustainable development. For this to be achieved, there must be strict national conservationist laws to enforce them.

As demonstrated above, there exists a necessary link between environmental ethics and sustainability. This relation is even clearer in African environmental philosophy. Both concepts are concerned with the following important goals: the protection of the natural environment for the welfare of future generations, respect for indigenous environmental values and knowledge systems, and the rights of indigenous people over their lands. These values also concur with traditional African environmental values. African environmental ethics teaches us that humans are not privileged species with special rights over the rest of nature, rather we are only a small part (and even the most destructive) of nature.

Aware of this human frailty and the need to forge a more composite worldview, indigenous African eco-philosophical values and practices thus promote the protection and conservation of nature. Because the environment is an integral part of the people's metaphysical and cosmological heritage, it can either improve or vitiate the physical and mental well-being of the individual depending on the kind of relationship he/she entertains with the environment (Chukwunoyenlum et al., 2013: p. 64). In this direction, there is a close connection between culture, nature and religion especially because most cultural beliefs and practices are also connected to nature and the environment. Hence, the sacred cannot exist without nature. Traditional African culture upholds and preserves the sacred through taboos and sanctions (Kouakou Bah, 2013: p. 3). It is through a healthy environment that life, physical and spiritual, is maintained or enhanced. However, these traditional metaphysico-religious beliefs and customs which encouraged environmental conservation are fading away and are gradually being supplanted by Western eco-philosophical beliefs and practices. One of the pylons Western colonialism in Africa was the imposition of the Christian religion. In so doing, they had to engage in a robust crusade against African religious beliefs and practices, which they considered as uncivilized, monstrous, and antithetical to development. Since the environment has metaphysical, social, religious, and economic value, any sustainable development endeavor must also be predicated on these salient elements. Indigenous African environmental beliefs and values can promote environmental conservation in diverse ways.

Firstly, the practice of totemism and the deification of some animal and plant species, taboos against the killing or hunting of such species, restriction of access to sacred sites, as well as the establishment of a relationship with some animal species are some of the abandoned environmentally-friendly practices that may help in the conservation of the environment. Although totemism is usually associated with sorcery and other malicious practices considered inimical to human development, it encourages the conservation of some animal or plant species. In the same connection, the killing of rare species, pregnant animals or animals found giving birth, hunting during unauthorized seasons, and the killing of young 
animals was strictly proscribed. In traditional Kom society, for example, there were particular seasons for hunting and this season is usually preceded by rituals and sacrifices to the deities. No hunting was allowed out of this period. The violation of such taboos, it is believed, can provoke the wrath of the gods and ancestor. Such transgressions could result in catastrophes such as disease outbreaks, sudden deaths, droughts, poor harvest, infertility, among other calamities. Taboos linked with the sacred thus contributed to the conservation of plant and animal species, and other natural resources considered as sacred. According to Kouakou Bah (2013: p. 2), some of the taboos prohibited the excessive use and exploitation of natural resources: 1) "ban in the exploitation of forest resources" (felling of trees, hunting, farming; 2) setting "forest on fire"; 3) "the discharging of human or domestic waste." There were also specially preserved forests for sacred and religious rites and procurement of medicine, which were not open to hunting and any resource acquisition, whatsoever. In Kom society, akuamifi was specially for such purposes. These eco-friendly practices and customs helped in conservation and sustainable use of the natural resources.

Secondly, African conservationist values can also boost the eco-tourism industry in Africa. Ecotourism is the careful development and management of tourism in areas of unspoiled natural beauty, so that the environment is preserved and the income from tourists contributes to its conservation. At heart of the idea of eco-tourism is the conservation of the environment and the improvement of the livelihood of the local population. Eco-tourism helps in community development by providing an alternative source of livelihood to local people which is more sustainable (Kiper, 2013: p. 785). Its aim is to conserve natural resources, especially biological diversity, create social and economic income for local communities, which are essential for sustainable development before the colonial encounter.

Thirdly, it can help in the conservation of known and yet-to-be discovered medicinal plants. There are many known and yet-to-be discovered species of medicinal plants which are lost because of the unsustainable use of the natural environment. Medicinal plants are a valuable source of new drugs and thousands of these plants and herbs are yet to be explored. If the unprecedented way in which the natural environment is being exploited is not curbed, humankind will be deprived of cures for many diseases whose treatment is still a challenge to modern medicine. Also, there are many of such medicinal plant and animal species which have been used by traditional healers for several centuries to treat different kinds of illnesses, which may be lost as a result of unrestricted and inconsiderate exploitation of the natural environment. African environmental values many help in the protection of some of these plant and animal species which have medicinal worth.

Fourthly, the beliefs and practices related to farming and hunting practices that are directly connected with environmental healing and conservation needs to be promoted. For example, fichuoh, the rituals that usually precede the planting 
season in Kom land. The fichuoh usually takes a one week of abstention, ritual prayers and sacrifices to the gods of fertility. Also, there was crop rotation, the practice of growing different crops on the same land in different farming seasons. The aim of crop rotation was to preserve the productive capacity of the soil, minimize pest and diseases, reduce chemical use, and manage nutrient requirement.

The practice of conserving parts of community forest for spiritual and economic use which was common in some African communities, if promoted, may not only help to preserve biodiversity, but also protect the environment against the adverse effects of climate change. As it has been observed, and in relation with our discussion so far, African "attitudes towards the environment may offer insights for redirecting the behaviour of technological societies towards a more sustainable path; and in general, global environmental problems can be better tackled through more cross-cultural and interdisciplinary approaches" (Kelbessa, 2006: p. 25). This caution results from the fact that indigenous African conception of nature still encourages sustainable use of natural resources which is one of the most reliable ways of healing the earth from wounds inflicted by humans, thereby extenuating the adverse effects of global climate change, which has been most fierce in Africa.

\section{Enhancing Sustainable Development through the Participation of Local People}

In spite of the multiple international agreements aimed at reducing greenhouse emissions (GHE) and curbing the global impact of climate change, very little has been done practically to achieve these laudable initiatives. There is an urgent need for environmental ethicists, whether Western or African, to work in collaboration with policy-makers, NGOs, and local populations especially peasant farmers to put into action the work of ethicists. This is because the contributions of professional environmental ethicists are mostly written in technical language and get lost in the scholarly journals where they are published and are hardly ever exploited by policy-makers, peasant farmers, pastoralists, and non-philosophers. In addition, modern environmental ethicists are not interested in peasant farmers and "other indigenous people in the world. They are more interested in academic knowledge and theoretical debate than in practical problems at the grass root level" (Kelbessa, 2006: p. 29).

In the same light, most developing countries do not take serious measures to respect and protect traditional knowledge and practices. And particularly so, most young people are not interested in learning traditional forms of wisdom (Kelbessa, 2006: p. 29). This laxity constitutes a serious obstacle to the valorization of indigenous knowledge for sustainable development particularly in Africa. There is, therefore, the need for commitment on the part of African governments, and other stakeholders, especially grass root people. This can only be achieved if governments take interest in the promotion of indigenous systems of knowledge and practices with regard to environmental protection. This cannot 
be realized without meeting some important social, political and cultural values. Elsewhere, we (Tosam \& Mbih, 2015) have outlined seven important requirements for sustainable development to be successful in Africa. Here, I will highlight five, which I consider germane for my analysis in this paper. These include the following preconditions: 1) good governance; 2) a focus on rural development; 3) empowering women; 4) investing in alternative and renewable energy; and 5) the need for educational reforms.

Firstly, democracy and good governance is fundamental for the management of natural resources. One of the fundamental causes of environmental degradation, which is also a key contributing factor for climate change in Africa, is corruption in the management of forest and natural resources, which result in illegal and unregulated exploitation of natural resources. Also, the mismanagement of crisis related to climate provokes violent conflicts that further degrade the environment. For example, as a result of desertification in some parts of the continent, caused by climate change, grazers have been forced into areas that were traditionally preserved for farming, thereby provoking fierce farmer-grazer conflicts. Transparency and accountability in the management of natural resources will help promote political stability and prevent the possibility of violent conflicts that result in the destruction of the natural environment. Environmental good governance promotes equal participation, transparency, and accountability, and respect for human rights (especially the right of indigenous people over their lands) in environmental management.

Secondly, for any human development to be sustainable, the rural people must be at the centre of it. When development begins from the rural areas it is likely to affect all sectors of society and is most likely going to be lasting than when it begins or is initiated from the upper class in society. This is crucial because rural people have direct contact with the environment through farming and exploitation of other natural resources.

Thirdly, and in connection with the need to involve rural people, is the need to empower women on the sustainable use of natural resources for improved quality of the environment (Tosam \& Mbih, 2015: p. 795). Because women make up more than half of the population in Africa and are directly involved in the land use and natural resources (farming, disposal of household waste etc.), they have a critical role to play in sustainable development. Rural communities and subsistence farmers are directly involved in environmental degradation. One of the principal reasons for the failure of national and regional environmental policies in Africa which were introduced in the wake of the Rio conference on environment and development (1992) has been that most of these policies favored a "top-down" (Kelbessa, 2014: p. 34) instead of the bottom-top approach. Also, the local people are knowledgeable about local environmental values and are best suited to implement them.

Fourthly, investing in renewable energy (wind and solar power) will also help in environmental conservation and sustainable development. Rapid population growth on the continent has exerted unendurable pressure on natural resources 
like water, forest, and agricultural farmland. Sustainable development in Africa will largely depend on alternative and renewable sources of energy alongside sustainable agricultural and infrastructural development. For example, more than $90 \%$ of African population depends on fuel wood for cooking, heating, and construction, which has a negative impact on tropical forest and the environment (Tosam \& Mbih, 2015: p. 796). Renewable energy will be essential for two reasons: it will help in the promotion of a healthy environment that is free of air and waterborne diseases as pressure on natural resources will be reduced; and, this is friendly to African environmental ethical, metaphysical and religious values. This will enhance the preservation of shrines and sacred places for rituals, and other indigenous religious practices.

Finally, these prerequisites of sustainable development can only be achieved if the efforts are accompanied by education. Environmental education will also help greatly in the direction of sustainable use of natural resources. People need to educate about the dangers of unsustainable farming practices, disposal of household and toxic waste on the environment and how that affects the health of the population.

\section{Conclusion}

Contrary to some scholars who maintain that Africans have little or nothing to contribute to environmental ethics because African ethics is essentially anthropocentric, I have shown that African environmental ethics is holistic. This environmental holism can be gauged through an African metaphysico-religious and moral outlook. African ontology is therefore not fundamentally anthropocentric or supernatural; it is holistic, encapsulating the normal and paranormal as extensions of each other. As we have seen, there are some indigenous African eco-philosophical beliefs and practices, which have been ignored, that may contribute to sustainable development. In discussing these, I have shown that there exists a nexus between environmental ethics and sustainability. Both environmental ethics and sustainability seek to guarantee a healthy environment for future generations, and to recognize the ecological values and the rights of indigenous people over their lands. To achieve these fundamental goals of environmental ethics and sustainability, African governments need to create an enabling environment that promotes traditional conservationist values, allowing local people to be directly involved in environmental management and protection. This is one of the surest ways through which the devastating effects of climate change, which has hit the continent the most, can be effectively mitigated. Furthermore, there is a need to forge a dialogue between traditional environmental knowledge and modern environmental ethics for a more sustainable and future friendly development.

\section{Conflicts of Interest}

The author declares no conflicts of interest regarding the publication of this paper. 


\section{References}

Behrens, K. G. (2010). Exploring African Holism with Respect to the Environment. Environmental Values, 19, 465-484. https://doi.org/10.3197/096327110X531561

Behrens, K. G. (2014). An African Relational Environmentalism and Moral Considerability. Environmental Ethics: An Interdisciplinary Journal Dedicated to the Philosophical Aspects of Environmental Problems, 36, 63-82. https://doi.org/10.5840/enviroethics20143615

Buju, B. (1998). The Ethical Dimension of Community. Nairobi: Paulines Publications.

Buju, B. (2009). Ecology and Ethical Responsibility from an African Perspective. In M. F. Murove (Ed.), African Ethics: An Anthology of Comparative and Applied Ethics (pp. 281-297). Scottville, MI: University of KwaZulu-Natal Press.

Chukwunoyenlum, A. C. K., Chukwuelobe, M., \& Ome, E. (2013). Philosophy, Religion and the Environment in Africa: The Challenge of Human Value Education and Sustainability. Open Journal of Social Sciences, 1, 62-72.

https://doi.org/10.4236/jss.2013.16011

Edwards, D. P., Sloan, S., Weng, L. F., Dirks, P., Sayer, J., \& Laurance, W. F. (2014). Mining and the African Environment. Conservation Letters, 7, 302-311. https://doi.org/10.1111/conl.12076

Gratani, M., Sutton, S. G., Butler, J. R. A., Bohensky, E. L., \& Foale, S. (2016). Indigenous Environmental Values as Human Values. Cogent Social Science, 2, 1-17. https://doi.org/10.1080/23311886.2016.1185811

Gudorf, C. E., \& Huchingson, J. E. (2010). Boundaries: A Casebook in Environmental Ethics. Washington DC: Georgetown University Press.

Holland, A. (2001). Sustainability. In D. Jamieson (Ed.), A Companion to Environmental Philosophy (pp. 390-401). Oxford: Blackwell Publishers Limited.

Ikuenobe, P. (2014). Traditional African Environmental Ethics and Colonial Legacy. International Journal of Philosophy and Theology, 2, 1-21.

https://doi.org/10.15640/ijpt.v2n4a1

Kelbessa, W. (2006). 'The Rehabilitation of Indigenous Environmental Ethics in Africa. Diogenes, 207, 17-34. https://doi.org/10.1177/0392192105055167

Kelbessa, W. (2014). Can African Environmental Ethics Contribute to Environmental Policy in African? Environmental Ethics, 36, 31-61.

https://doi.org/10.5840/enviroethics20143614

Kiper, T. (2013). The Role of Ecotoursim in Sustainable Development. https://www.intechopen.com/books/advances-in-landscape-architecture/role-of-ecotou rism-in-sustainable-development https://doi.org/10.5772/55749

Kossof, D., Dubbin, W. E., Alfredsson, M., Edwards, S. J., Macklin, M. G., \& Hudson-Edwards, K. A. (2014). Mines Tailings Dams: Characterisitics, Failures and Impacts. Applied Geochemistry, 51, 229-245. https://doi.org/10.1016/j.apgeochem.2014.09.010

Kouakou, B. J.-P. (2013). The Contribution of the Sacred in Traditional African Societies to Environmental Ethics. Anthropology, 1, 1-3.

Maathai, W. (2010). We Are Called to Help the Earth to Heal. In K. D. Moore, \& M. P. Nelson (Eds.), Moral Ground: Ethical Action for a Planet in Peril (pp. 275-278). San Antonio, TX: Trinity University Press.

Michael, J. (2005). Environmental Ethics and Sustainable Development: Ethical and Hu- 
man Rights Issues in Implementing Indigenous Rights. Macquarie Journal of International and Comparative Environmental Law, 2, 105-120.

Molefe, M. (2015). A Rejection of Humanism in African Moral Tradition. Theoria, 60, 57-77. https://doi.org/10.3167/th.2015.6214304

Naess, A. (1989). Ecology, Community, and Lifestyle: Outline of an Ecosophy. Cambridge, Cambridge University Press. https://doi.org/10.1017/CBO9780511525599

Ojomo, P. A. (2011). Environmental Ethics: An African Understanding. Journal of Pan-African Studies, 4, 101-113.

Senra, R. (2019). Brazil's Dam Disaster: Looking for Bodies, Looking for Answers. BBC News. https://www.bbc.co.uk/news/resources/idt-sh/brazil_dam_disaster

Tempels, P. (1969). Bantu Philosophy (Trans. Rubbens, A.). Paris: Prensence Africaine.

Tosam, M. J. (2016). The Theocentric and Anthropocentric Foundations of African Ethics. In M. J. Tosam, \& P. Takov (Eds.), Philosophy in Culture: A Cross-Cultural Perspective (pp. 65-85). Bamenda: Langaa RPCIG.

Tosam, M. J., \& Mbih, R. A. (2015). Climate Change, Health, and Sustainable Development in Africa. Environment, Development and Sustainability: A Multidisciplinary Approach to the Theory and Practice of Sustainable Development, 17, 787-800. https://doi.org/10.1007/s10668-014-9575-0

UNECA United Nations Economic Commission for Africa Press (2012). Africa Loses from Poor Management of Natural Resources.

http://www1.uneca.org/ArticleDetail/tabid/3018/ArticleId/2196/Africa-loses-from-poo r-management-of-natural-resources-says-Lopes.aspx

Van Horn, G. (2018). Ethics and Sustainability. Center for Humans and Nature: Expanding Our Natural and Civic Imagination. https://iseethics.files.wordpress.com/2013/09/ethics_and_sustainability_primer.pdf

WHO (2015). WHO Publishes List of Top Emerging Diseases Likely to Cause Major Epidemics.

https://www.who.int/medicines/ebola-treatment/WHO-list-of-top-emerging-diseases/e $\underline{\mathrm{n}}$

Wiredu, K. (1980). Philosophy and an African Culture. Cambridge: Cambridge University Press.

Wiredu, K. (1983). Morality and Religion in Akan Thought. In H. O. Oruka, \& D. A. Masolo (Eds.), Philosophy and Cultures (pp. 7-19). Nairobi: BookWise.

Wiredu, K. (1994). Philosophy, Humankind and the Environment. In H. O. Oruka (Ed.), Philosophy, Humanity, and Ecology: Philosophy of Nature and Environmental Ethics (Vol. 1, pp. 30-48). Nairobi: ACT Press and AAS.

World Commission on Environment and Development (WCED) (1987). Our Common Human Future. New York: Oxford University Press. 